\title{
RUSSELL AND THE BOER WAR: FROM IMPERIALIST TO ANTI-IMPERIALIST
}

\section{David Blitz}

Philosophy and Honors Program / Central Connecticut State U.

New Britain, CT 06050, USA

BLITZ@MAIL.cCsU.EDU

$\mathrm{B}$ ertrand Russell's philosophy of war and peace, like other aspects of his philosophy, underwent an evolution during the course of his long life, though his commitment to peace and his opposition to war, like his commitment to logic and his distaste for mysticism, was strongly held once it had been established. ${ }^{1}$ How Russell's commitment to peace became established is the subject of this paper. ${ }^{2}$ For Russell was not always an opponent of war: at the outbreak of the Boer (or South African) War in I899, Russell, then twenty-seven years of age, was a defender of British imperialism. But by the end of that war, Russell had abandoned this view and had shifted to an anti-imperialist and pro-peace stance which would characterize the rest of his life. My claim for this paper is the following: contrary to published views on the subject-both by Russell himself and one of his most able political biographers-

${ }^{1}$ Nonetheless, Russell's philosophy of war and peace, like his philosophy of logic and mysticism, was not a simple one, since he took into account not only general principles, but also concrete circumstances. Although Russell's position was a basically pacifist one after the debate with Louis Couturat that is analyzed in this paper, he nonetheless was a supporter of the Second World War once it had broken out. Similarly, though his commitment to an analytic approach informed by logic was characteristic of all of his later work, he nonetheless had moments, such as the I90I experience discussed below, which he termed "mystical".

${ }^{2}$ The editorial assistance of Kenneth Blackwell and the archival assistance of Carl Spadoni of the McMaster Archives were essential to the writing of this paper. 
Russell's move away from liberal imperialism was neither the result of what has been referred to as his I9OI "conversion experience", nor a product of later reflections on his part. Rather, it occurred in the course of Russell's debate with the French logician Louis Couturat during the year 1900. Not only was Russell unable to refute Couturat's pacifist arguments; but by his silence and lack of reply he acknowledged that Couturat had refuted Russell's own best efforts at defending imperialism and the rule of the most powerful.

\section{THE I9OI CONVERSION EXPERIENCE}

I will begin with a quotation from Russell's Autobiography, dealing with the well known I90I "conversion experience". ${ }^{3}$ On Io February, having returned to the home of Alfred North Whitehead and his wife after attending a reading of Gilbert Murray's new translation of a Greek play, Russell found Mrs. Whitehead in great pain, suffering from severe angina or a heart attack. Overwhelmed by her suffering, Russell went through what has been described as his "conversion experience":

Suddenly the ground seemed to give way beneath me, and I found myself in quite another region. Within five minutes I went through some such reflections as the following: the loneliness of the human soul is unendurable; nothing can penetrate it except the highest intensity of the sort of love that religious teachers have preached; whatever does not spring from this motive is harmful, or at best useless; it follows that war is wrong, that a public school education is abominable, that the use of force is to be deprecated, and that in human relations one should penetrate to the core of loneliness in each person and speak to that. (Auto., I: 146; emphasis added)

${ }^{3}$ Some commentators have situated the essence of the conversion experience in Russell's childhood loss of his parents, as Andrew Brink does in his Bertrand Russell: the Psychobiography of a Moralist (Atlantic Highlands, N.J.: Humanities P., 1989). Victor Lowe in his chapter on Russell in Alfred North Whitehead: the Man and His Work, Vol .

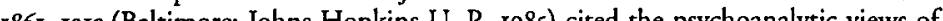
and Mrs. Bennett Simon, who argued that Russell had identified with the Whiteheads son, Eric, who was then about the same age as Russell was when his mother died. (See Simon and Simon, "The Pacifist Turn", Russell, no. 13 (spring 1974): II-12, 17-24.) Stil others, such as Ray Monk in Bertrand Russell: the Spirit of Solitude, see in the anguish Russell felt an indication of a repressed love for Evelyn Whitehead at a time when Russell was falling out of love with his own wife, Alys.
Russell continued:

At the end of those five minutes, I had become a completely different person For a time, a sort of mystic illumination possessed me. I felt that I knew the inmost thoughts of everybody that I met in the street, and though this was, no doubt, a delusion, I did in actual fact find myself in far closer touch than previously with all my friends, and many of my acquaintances. Having been an Imperialist, I became during those five minutes a pro-Boer and a Pacifist. (Ibid.; emphasis added)

This is indeed a startling statement, and in what follows I will be especially concerned with the two italicized statements, "[I]t follows that war is wrong," and "Having been an Imperialist, I became during those five minutes a pro-Boer and a Pacifist." 4 I will also focus on a critical statement made by Alan Ryan, who attempts to debunk the whole incident:

Russell has left a dramatic and moving account of his sudden and decisive breach with imperialism. One day, in 1901, he returned from a bicycle expedition to find Mrs. Whitehead suffering terrible pain from a heart attack; the experience revealed to him the appalling loneliness of suffering and turned him on the instant from a bellicose imperialist into a lover of his fellows who wished them nothing but good.s

\section{But this is irony on Ryan's part, for he continues:}

His letters to Couturat reveal this was a piece of myth-making. The incident of Mrs. Whitehead's heart attack undoubtedly made a difference to his life, but it was a personal rather than a political difference. He realized how much he cared for Mrs. Whitehead, was perhaps prodded towards a realization that he no longer cared for Alys, and had his already strong sense of isolation reinforced. It is less clear that it altered his political views; some time afterwards, he told Couturat all about Mrs. Whitehead's illness and his own distressed reaction to

4 This part of Russell's Autobiography, published in 1967, two-thirds of a century after the event, was first composed by Russell in I93I, though this was still some 30 years after the fact. Nonetheless, it is consistent with what Russell wrote to Lady Ottoline Morrell as early as 19Ir: "At the beginning of the war, I was an imperialist more or less. In the as early as X91I: "At the beginning of the war, I was an imperialist more or less. In the brought with it a love of humanity and a horror of force, and incidentally made me a pro-Boer" (Russell to Morrell, no. 49, 2 May I9II).

' Alan Ryan, Bertrand Russell: a Political Life (New York: Hill and Wang, 1988), p. 34. 
it in a letter in which he reiterated and defended his previous moderate imperialism. (Ibid.)

Now this is interesting, and is important if true, since it would refute a major part of the conversion story-that part concerning Russell's conversion to an anti-imperialist and anti-war position. As evidence for his claim, Ryan cites, though he does not quote from a letter by Russell to the French logician Louis Couturat, dated 5 October 1903. Ryan's position appears to be based on an earlier analysis by Richard Rempel. ${ }^{6}$ Rempel has argued that it was not until Russell undertook his campaign for free trade in 1903 that he fully broke with imperialism. Though the process had begun with the Couturat debate and had reached a "crisis" in the I90I conversion experience, it was not determined or concluded by the latter. Rempel notes that "Nevertheless, Russell's renunciation of imperialism was a slower process than he claimed and it can only be charted in the Couturat correspondence" (p. 427). An examination of the Russell-Couturat correspondence at the Russell Archives in McMaster University reveals an even more complicated story. ${ }^{7}$ Indeed, both Russell and Ryan were wrong about how Russell had changed his mind from a liberal imperialist stance to the beginnings of an anti-war and pacifist viewpoint which would largely, though not exclusively, inform his political writings and his practical work thereafter.

Russell was wrong in imputing his conversion solely to the incident

${ }^{6}$ Richard Rempel, "From Imperialism to Free Trade: Couturat, Halévy and Russell's First Crusade", Journal of the History of Ideas, 40 (1979): 423-43.

7 See L. Couturat to Russell, RAI 7IO.048606-.04864I and REC. ACQ. 422. The latter group of letters was documented by Anne-Françoise Schmid in an article, "La Correspondence inédite Couturat-Russell", which appeared, in French, in Dialectica, 37 (1983): 76-109. She had first presented her findings to a conference on Couturat held in Paris, 8-9 June 1977 at the Ecole Normale Supérieure, the proceedings of which have been published as a monograph, in L'Oeuvre de Louis Couturat (1868-1914) ... de Leibniz à Russell ... (Paris: Presses de l'École Normale Supérieure, 1983). Schmid notes that correspondence had been found in 1975 at the CDELI (Centre de Documentation et d'Études sur la Langue Internationale), part of the public library of the town of La Chaux-deFonds in Switzerland. The 198 letters and postcards between Russell and Couturat at this location, all in French, date from 1897 to I913 and were deposited in this documentation centre for international languages because of Couturat's interest in the cause. None had previously been published in full before Nicholas Griffin included a few of Russell's letters to Couturat in $S L B R$ r. with Mrs. Whitehead in 1901, while Ryan was also wrong in claiming that Russell still defended a "moderate imperialist" view in 1903. A careful reading of the Russell-Couturat correspondence shows that Russell engaged in and lost a debate over imperialism and war with Couturat in 1900, priming him for his later anti-war and anti-imperialist views.

\section{LOUIS COUTURAT AND HIS CORRESPONDENCE WITH RUSSELI}

Louis Couturat (1868-1914) ${ }^{8}$ was a French philosopher who was initially influenced by George Boole's algebraic treatment of logic, and who was also highly interested in the philosophy of mathematics. This led him to become a student of Russell's new logic. In 1897 Russell reviewed Couturat's book De l'Infini mathématique (1896) and a year later Russell responded to Couturat's review of his own book, An Essay on the Foundations of Geometry (1897). Their correspondence began in 1897, and continued on topics of both logic and politics through 1905, when it tapered off to occasional notes through 1913, many of which dealt with Couturat's subsequent focus on international languages.

Couturat played an important role in Russell's early philosophical career, not only in arranging for Russell's book on geometry to be translated into French, to which Russell contributed a preface, extensive revisions and an appendix of mathematical notes, but also by inviting Russell to the 1900 international conference on philosophy. This was a significant turning-point in Russell's intellectual career, for it was at that conference that Russell met Giuseppe Peano and fully realized the crucial importance of the new formalism for mathematical logic. This was the impetus for the work which Russell and A. N. Whitehead would perfect in their three-volume Principia Mathematica (1910-13). Coincidentally, both Russell and Couturat, independently of each other, wrote books on Leibniz dealing with his logic as the basis for his metaphysics. Couturat provided hitherto unknown texts in support of Russell's claim of an inconsistency at the heart of Leibniz' logic. As a conse-

\footnotetext{
8 Coururat's main philosophical works are De l'Infini mathématique (1896), De Platonicis mythis (1896), La Logique de Leibniz (1901), Opuscules et fragments inédits de Leibniz (1903), L'Algebre de la logique (1905), and Les Principes des mathématiques (1905); works by Couturat after 1905 until his death in 1914 in a car accident were devoted to studies of international languages such as Esperanto and Ido.
} 
quence, Couturat was someone whose views Russell took very seriously, at least in the period from 1899 to $1905 . .^{9}$ This included, as I will argue below, not only Couturat's views on Leibniz and logic, but also his views on imperialism, war and peace.

The correspondence between the two for $1897-99$ largely concerned Couturat's efforts to find a French translator for Russell's work on geometry, and the progress of the translation. ${ }^{\mathrm{TO}} \mathrm{A}$ new subject arose, when on 28 June 1899 Couturat wrote to Russell to say: "I am officially mandated by the Organizing Committee of which I am a member to tell you that an international congress of philosophy will be held in Paris in 1900, and to invite you to attend."

On I3 August 1899 Russell noted that he has just heard of the conviction of Dreyfus, the French Army captain of Jewish origin who was wrongly accused of treason in the major political event in France at the end of the nineteenth century. Couturat, like Russell, was for Dreyfus and opposed the right-wing conspiracy against Dreyfus that ultimately would be unmasked. On 30 November Russell wrote to Couturat, with the International Conference on philosophy in mind, "I hope that no international misunderstandings will occur between now and then. So many of them are possible that one can never be sure of even the near future." In a long letter of 3 December 1899 , Couturat responded, bringing up not only the Dreyfus affair, the nature of which was rapidly agreed upon by the two, but also a further "international misunderstanding", the war that had recently broken out between Great Britain and the Boers in South Africa.

${ }^{9}$ Later, Russell became disenchanted with Couturat for two reasons: his somewhat simplistic presentation of mathematical logic, and subsequently his giving up of mathematical logic and philosophy to devote himself to propaganda work for an international artificial language (first Esperanto, then Ido). Russell attempted to rouse Couturat from what he considered as his abandonment of serious work, but by the early Igros, just before Couturat's premature death, had given up on the project. See Russell's letter (no. 400) to Ottoline Morrell of 25 March 1912, where Russell reacts negatively to letters from both Couturat and Peano on the subject of international languages.

${ }^{10}$ The first letter in the Russell Archives is from Couturat to Russell, dated 3 October 1897, thanking Russell for his review of Couturat's book, De l'infini mathématique. Russell's book was translated by Albert Cadenat, a mathematics professor at the College de Saint-Claude, as Essai sur les fondements de la géométrie in 190r (Paris: GauthierVillars). Russell reviewed the translation, which contained an added section: Couturat's "Lexique philosophique" (pp. 255-60).

\section{THE BOER WAR}

A brief review of the context and facts of the Boer War is necessary in order to properly situate Russell's reaction to its ebbs and flows. The Boer War (1899-1902) spanned the end of the nineteenth century and the beginning of the twentieth. ${ }^{\text {II }}$ The Boers were Dutch immigrants to the southern part of Africa, where a colony had been established in 1652 for the purposes of replenishing ships passing by the Cape, and to which colonists, as "free burghers", were added as of 1657. After having been occupied by England twice during the course of the Napoleonic Wars, the Cape Colony was ceded to Britain by the 1814 Treaty of Paris, for which a compensation of six million pounds was paid to the Dutch government. The abolition of slavery in the British Empire in 1834 and what was perceived as a lenient British policy to the black natives led to conflict with the Boers, who in 1835-37 undertook their "Great Trek" north, away from the British settlement. They settled in the area north of the Vaal River - the Transvaal-as well as in Natal. Natal was eventually annexed by Great Britain ( 1843 ), while the Boers subsequently founded the Orange Free State (1854).

Thus by mid-nineteenth century the southern horn of Africa was divided into four territories. Two were British-dominated areas: the original Cape Colony and the newly annexed Natal, while two were Boer dominated areas: the Transvaal (known as the South African Republic after 1856) and the Orange Free State. Further conflict was to follow, as the British manoeuvred to form a single federation of the four colonies, while the Boers resisted efforts to annex their territories.

The British succeeded in annexing the South African Republic in 1877 , but within three years, the Boers rose against British rule in what is sometimes referred to as the First Boer War (I880-8I). This was settled by self-government for the Transvaal, combined with British sovereignty

II For further information on the Boer War, see Iain Smith, The Origins of the South African War r89(London: Leo Cooper, 1975), and A. N. Porter, The Origins of the South African War: Joseph Chamberlain and the Diplomacy of Imperialism (New York: St. Martin's P., 1980) For contemporaneous portraits, see James Bryce et al., Briton and Boer: Both Sides of the South African Question (New York: Harper and Brothers, 1900), and A. Conan Doyle, The Great Boer War (New York: McClure, Phillips, 1900) 
in matters of foreign policy, after what was essentially a British defeat. The conflict, which economically bore on who would control the rich diamond fields, was intensified by the further discovery of gold in 1886 on the Witwatersrand in southern Transvaal. Within their two states, the Boers took political measures to exclude "outlanders" (including the British) from the vote, while elements of the British dominated Cape Colony, under the leadership of Leander Jameson, attempted an ill-fated invasion of the Transvaal, known as "Jameson's Raid" (1895). This was the immediate background to the outbreak of war, which occurred on 12 October 1899. The war, which pitted the citizen Boer army-which was not in uniform-against the professional British army, progressed through three stages.

In the first stage, from mid-October 1899 to early February 1900 the Boers, who had taken the initiative to attack, were successful against outnumbered British troops. The British suffered considerable losses and were on the defensive. These setbacks influenced Russell's views, in particular during what is known as the "Black Week" of British defeats in three major battles from Io to Is December 1899 .

In the second stage, from mid-February 1900 to the end of September of that year, the British, reinforced by troops from India, mounted a counter-offensive, forcing the Boer leader, Paul Kruger, to flee to Europe. But the Boer irregulars were not defeated, and they mounted a harassing campaign of small-scale surprise skirmishes that became known as "guerrilla warfare".

This led to a third stage of the war which lasted from the end of 1900 until March of 1902 . The British used a new tactic- that of concentrating the non-combatant Boers, mainly women and children, in forced settlements in fenced-off areas surrounded by blockhouses. These became known, at the time, as "concentration camps", and eventually up to 120,000 Boer women and children were confined in them, of which some 20,000 are estimated to have died of disease and hunger. ${ }^{\mathrm{I2}}$

The blockhouse tactic was successful in preventing the mounting of major campaigns by the Boers, but could not put an end to skirmishing by the Boer irregulars. The war was officially concluded by the signing

${ }^{12}$ Belfield in The Boer War gives the following figures: in 1902 there were 114,000 persons in the concentration camps, of which 95,000 were women and children. The estimate of 20,000 deaths in the camps covers the period September 1900 to June 1902. on 30 May 1902 of a peace treaty at Vereeniging, which guaranteed that no Boer rebels would be executed and which provided a sum of three million pounds to help restart the shattered economy of the area. The Boers accepted British sovereignty, but were promised self-government in the near future, which was ultimately provided by the South Africa Act of 20 September 1909 (effective 3I May 19ro).

It is interesting to note that this war gave rise to two terms which would be important in later twentieth-century war: concentration camps and guerrilla warfare. But let us return to Russell now, and see how he fared in the context of the British imperial adventure in southern Africa.

\section{RUSSELL'S DEBATE WITH COUTURAT ON THE BOER WAR}

Prompted by Couturat to respond to the question of the Boer War, Russell reacted in the context of the "Black Week" of mid-December I899, characterized by Boer victories over the English troops during the first phase of the war:

I am so crushed by my country's disgrace that I am unable to think of anything else-philosophy seems to be no more than child's play in comparison with recent events. I cannot help but to hope for the success of our armies, in the first place because of stupid and instinctive patriotism, but also for more profound reasons. English imperialism is inspired (among the educated) by the idea of Rome, by the history of Mommsen (whose maxims will justify anything), by Carlyle and by Nietzsche, and finally by Darwin and evolution. Here is an erroneous sentiment, no doubt, but one which is sufficiently respectable; "intellectuals" are not opposed to it for the greater part: to the contrary, in general they approve of this sentiment, which supports itself through a moral scepticism generated by logical analysis. I am able to scoff at that when things are going well, but for the moment I find myself, reluctantly, carried away by love of country. (18 Dec. 1899$)^{13}$

Couturat, who had just recently engaged in a newspaper debate over Kant and the problem of peace, ${ }^{\mathrm{I} 4}$ could not let this pass, and he

${ }^{13}$ The correspondence was carried out entirely in French, of which Russell's, though lacking in some of the subtleties of his English prose, was excellent. All translations are by the author of this paper. All underlining in the letters, in conformity with modern typographic standards, is rendered in italics.

14 "Letres à Brunetière, sur le pacifisme de Kant", Le Temps, 27 March and I April 1899 
retorted immediately, in a letter written on the day before Christmas I899. After sympathizing with Russell's patriotism, which he accepted as the legitimate love of one's own country, Couturat warned of chauvinism and jingoism, a perversion of patriotism used to justify conquest of other countries:

What is less respectable, or at any rate less sympathetic, is imperialism, which you have skilfully analyzed in terms of its historical and philosophical sources. The philosophy which inspires it, or rather which it uses to mask itself is especially hideous. At its centre, once all the historical, evolutionary and sociological sophisms have been removed, the ethics of the strongest, the Bismarckian maxim: force takes precedence over law and rights. It's the immoral and cynical consecration of success, the adoration of the "fait accompli" and of brutal force; it's also the Jesuit maxim: the ends justify the means. This also, unfortunately, is part of your national traditions, and in practice is translated into egoistic and aggressive chauvinism, an insatiable thirst for conquest and domination; though it may invoke the glorious (but hardly enviable) memory of Rome, it necessarily provokes the antipathy and the distrust of the other nations. (24 Dec. 1899)

Russell responded briefly in a letter of 16 January 1900 , but deliberated more on the matter and produced a lengthy letter dated 24 March, where he stated that the difference with Couturat was not only political, but above all philosophical:

... I'm utilitarian, and I wouldn't have expected to find in the thinking of a philosopher the opposition which you make between interest and justice. It seems to me that there are bigger and smaller interests, and that justice is always on the side of the bigger interest; or, to speak absolutely, on the side of the human species. Thus, I do not desire a state of law ["état juridique"] between nations, which would seem to me to stop all progress. If we had followed the law, Holland would still be subject to Spain, and America would be divided between Spain and Holland. The unity of Germany and Italy would have been impossible, and in the United States, the southern states would have become independent and would have maintained slavery. As for Turkey, a state of law

has been maintained, and I find that this has stopped Russia from conquering Constantinople, which she should have. (24 March 1900)

To cap his argument, Russell made what is a most surprising claim, arguing for continental-wide spheres of colonial domination for the three great powers of England, America, and Russia, a view which I'll refer to as Russell's theory of "continental imperialism":

In general it seems to me that large empires are worth more than small ones, because there are fewer borders, wars are not as disastrous or as frequent, and there are greater chances of having able governors. In any case, the consolidation of borders will diminish the chance of wars. For this reason, I would wish to see all of Asia (including India) belong to Russia, all of Africa to England, and all of America to the United States. Then we could hope for a durable peace and civilized government. (Ibid.)

This move is a typical one by Russell. Challenged by Couturat to defend his position on the Boer War, Russell shifted to a more general level of argument. He developed a theory of "continental imperialism", which, when countered by Couturat, would leave Russell no option but to abandon his stance. In a sixteen-page reply of 6 April, Couturat loosed his formidable arsenal of counter-argument: he taxed Russell with being inconsistent in the reasons for his support of the British intervention, and duped by imperialist propaganda:

I say that I am astonished by your principles, because it seems to me that you have changed them in the last six months. On Oct. 2I you recognized that "patriotism is the source of many crimes." In January, you said that when the war began it seemed to you to be very unjust, ${ }^{15}$ and now you try to prove the opposite, that is to say, that the Boers are in the wrong, and that the English are doing no more than defend themselves against their machinations.... And now you admit no consideration of justice among nations, and you proclaim the higher rule of national interest and the right of the strongest. I render homage to the frankness of these statements; but then, what can we make of the previous ones? You will of course understand that if I compare your statements of different dates, this is not in order to obtain pleasure from placing you in contradiction with yourself (you have the right to change opinions, even as concerns principles), but in order to straighten out your real thought, and invite you to reflect on the motives which guide them. May I admit to you: I have the feeling that your first statements were personal, and that the later ones are more the echo of public opinion and your circle [of acquaintances] and milieu. I recognize in them the old English philosophical tradition of Hobbes and other empiricist

is Note added by Couturat to this letter: "(I should add, with a bit of sting, that it seemed unjust to you because the English thought they were the stronger, but that it then appeared to be just to you, because the English found that they were really the weaker.)" 
and materialist political thinkers who base right on force. You told me yourself (on Dec. 8 , in an extremely instructive letter) that imperialism was inspired by the maxims of Mommsen, Carlyle and Nietzsche, which justify anything and everything. It seems to me now that you have been taken in by them. (6 April I900)

This is strong language and harsh critique. Couturat then invoked Kant against force and for peace in international relations:

No matter what, I remain faithful to my principles of international law, which are those of Kant and not those of Bismarck or Napoleon, and which are in conformity with the most noble and generous traditions of the French spirit. Every nationality has the right to exist and be independent, and the suppression of a nation is a crime analogous to that of the killing of a person; all brutal conquest is armed robbery. As to conflicts of interest among nations, they can and must be resolved by judicial procedures, and not by war, which is as absurd and barbarous as duels among individuals. (Ibid.)

Couturat's reference to the principles of Kant is significant. Kant's most important article on the subject is "Perpetual Peace", written in $1795 .^{16}$ In it Kant set out a number of "preliminary articles for perpetual peace among states", including the call for the abolition of standing armies. An essential part of Kant's argument was to generalize the social contract from individuals within a state to states within the community of nations. The natural state for sovereign individuals is one of war of all against all; but it is in the interest of each individual to forego part of his sovereignty in order to achieve a social state of peace. Similarly, the natural state of sovereign nations is one of external conflict breaking into war; analogously, it would be in the interests of each to forego part of its sovereignty to enter in to a "league of nations" enjoying perpetual peace. The very talk, among intellectuals and statesmen, of "laws of war" indicates that, despite their belief in war as an option, they implicitly recognize that it is limited by a "greater moral disposition to become master of the evil principle" (Kant, p. 99) which, if further generalized, would lead to the overcoming of the evil principle of war itself.

It is in this context that we can understand Couturat's critique of

${ }^{6}$ Immanuel Kant, On History, ed. Lewis White Beck (Indianapolis: Bobbs-Merrill, 1957), pp. 85-91 passim.

\section{7) pp. $85-9$ passim.}

England's refusal to obey international agreements, especially the Hague convention on settling disputes through mediation, ${ }^{17}$ a refusal which he termed a "crime against humanity": "England has contributed as best it could, through arrogance, ambition, and egoism, to the negation of the results of the Hague Conference, and has pushed into the future the era of non-violence: this is a step back for civilization, a return towards barbarity; it's a crime against humanity ['crime contre l'humanité']" (6 April 1900). From the Kantian ethical perspective Couturat espoused, the signing of the Hague convention had marked a step forward in the progress towards the "league of nations" and "perpetual peace" which represented the future for humanity. England's repudiation of these principles, through the act of war against the Boers, was therefore a "crime against humanity".

Couturat had two potent allies on his side: Kant's argument for perpetual peace, and the Hague convention. Russell, as it turned out, was on his own and had to improvise, initially drawing on an analogy to modern geometry to defend his political axioms. He responded to Couturat in a letter of 5 May 1900 :

I am no Kantian in ethics, but rather I'm more platonistic (as in logic) than anything else that is modern. Yet I believe that it's impossible to apply theoretical ethics in politics, or even in private life, since circumstances are so complicated that we don't know how to accomplish the necessary reasoning. As a result we have to make an immediate appeal to common sense for our middle axioms. (5 May 1900) ${ }^{18}$

Russell defended what he considered the "common-sense" political axiom that empire is good so long as it benefits both the colonial power and the colonials-the point of view of "liberal imperialism". ${ }^{19}$ Starting

17 The first Hague convention, adopted 29 July 1899 and to which England subscribed, was titled "Convention for the Pacific Settlement of International Disputes". It called, in Article r, for states to use their "best efforts to insure the pacific settlement of international disputes" and, in Article 3 , for mediation by one or more friendly powers "before an appeal to arms" in cases of serious disagreement. The full text is available at http:/www.tufts.edu/departments/fletcher/multi/texts/BHor4.txt, which is part of the web site of the Tuft University Multilateral Project, containing major documents in international relations.

${ }^{18}$ A full translation of this letter (with stylistic differences) is contained in $S L B R$, I: 198-20I. In French, Russell used the term "axiomes majeurs" for "middle axioms".

19 Note that Russell's viewpoint, although imperialist and chauvinist, was nonetheless

$\longrightarrow$ 
from this axiomatic basis, he stressed two consequences: "There are two great tasks for a statesman in foreign affairs: (a) preserve and defend peace (b) spread civilized government" (ibid.).

Russell continued his letter with an argument based on anthropology, which provided him with a theoretical justification of the European mission to govern the non-Europeans, and thereby gradually improve the circumstances of the "savages". ${ }^{20}$ This chauvinist and imperialist argument was nonetheless well within the scope of the liberal ideology of Russell's time:

If you had read any books on anthropology, you'd know what a savage land really is, and what are the benefits of civilized government. I desire that no part of the world not be governed by a European race-not any, to begin my argument. Now, the stronger a nation is, the less it has to fear of uprisings by the

a liberal and not a conservative one. Stephen Jay Gould, in analyzing Darwin's thinking on the same subject, has distinguished between proponents of an "improvable" and those of a "fixed" hierarchy. (See his Ever Since Darwin [New York: Norton, 1977]). Both liberals and conservatives agreed that the "native population" was inferior, lower on the scale of human evolution or development. But the liberals argued for an "improvable" hierarchy whereby individuals from the lower race could be improved and achieve the standards of the higher race through acculturation and education. Eventually, the whole group would improve its circumstances. This argument, by the way, also applied to gender. Conservatives, arguing for a fixed hierarchy, saw no hope for individual improvement and did not even consider the possibility of group progress for the inferior races.

20 The nineteenth century debate between scholars who called the academic study of non-Europeans "anthropology" and those who called it "ethnography", and the victory of the former over the latter by the end of the century are important for understanding Russell's views on "savage" peoples. The anthropological viewpoint provided him with a "scientific" argument for the superiority of European civilization. Ethnographers in the early nineteenth century, such as Richard Pritchard, were primarily concerned to describe the various characteristics-especially cultural ones- which distinguished one ethnic group from another; considerations of "higher" and "lower", though present, were secondary (see Pritchard's Researches into the Physical History of Mankind, 5 vols. [London: Sherwood, Gilbert and Piper, 1847]). The anthropologists, best represented in England during the 1860 s by James Hunt, president of the Anthropological Society of London and editor of its journal, The Anthropological Review, focused primarily on establishing "lawful" relations of higher and lower among the various races, as identified and distinguished by physical characteristics. The anthropological viewpoint was less sympathetic to non-Europeans and more chauvinist than the ethnographic one. By the time of Russell's attendance at university, the anthropological viewpoint was dominant, and his use of the term "savages" in this context indicates its influence over his thinking at this time. savages-so the strongest, caeteris paribus, are the best colonists. But it is only within very narrow limits that I'm on the side of the stronger. And I find that the principles which apply to Europe, where nations are now fairly well defined, are quite different from those that apply elsewhere. (Ibid.)

Having stated his views on colonialism, Russell then concluded on a more philosophical note: "I differ from you on the topic of the nature of political axioms. I find that we should be postulating ends-you, with Kant, that we should postulate maxims of conduct" (ibid.). Russell was willing to accept war as a technical means to an imperial end; Couturat, in his immediate response, stressed the importance of the moral means:

The only way to avoid wars is through moral means: moderation of desires, and the respect of the rights and the liberties of others. Outside that, there is no way for peace to be possible. You say "the fewer the number of states, the less boundaries and militarism there will be." History disproves you: isn't it only since Germany has been unified that it has become militarist and a concern for the peace of the world? The suppression (through annexation or division) of small states like Poland is not only a crime (from my point of view); it's also a political mistake, from the point of view of interests, since small states serve as buffers between the big ones. (13 May 1900)

Couturat thereby reaffirmed his commitment to Kantian ethics, which form a "rigid and austere guide which is infallible and always clear" (ibid.). He then went on to charge Russell with illogical reasoning, and applied the following reductio ad absurdum to Russell's argument for imperialism:

You admit that patriotism is bad in general, and you think that I find it bad as concerns your country, but good as concerns the Boers. You are mistaken: I find it legitimate and respectable for all peoples, both big and small. But I distinguish between patriotism and the spirit of conquest, which carries the name of imperialism and which dreams of world domination. Finally, your thesis can be refuted by reductio ad absurdum: you say: the fewer the number of states, the smaller the chance of war. But, if there were only two left on the earth, they would find some means to fight; therefore, there should only be one, which apparently is the British empire. If you don't want to go that far (and despite everything, this goal will not be achieved) it's better to respect the independence of other states, and not infringe on them. (Ibid.)

This is strong language indeed: Russell's theory of "continental imperial- 
ism" is inconsistent!

Russell's argument for continental imperialism can be restated thus:

(RI) The goal is to eliminate wars as far as possible. (This is an ethical axiom for Russell.)

(R2) Boundary disputes are the basic cause of war. (This is a statement of political fact.)

(R3) Therefore, in order to have fewer wars, there should be fewer boundaries between and among the great powers. (This follows from $\mathrm{RI}$ and R2.)

(R4) No one power should control the world. (This appears as a political axiom.)

(Rs) From this it follows that the world should be divided among a few great powers, with each controlling a continent; thereby producing a peaceful status quo among the imperial powers which would share the smallest possible number and extent of boundaries.

Couturat's argument can be restated as follows:

(CI) Great powers will not voluntarily give up any part of their imperial holdings.

(C2) Even if there were only two great powers left, they would fight each other.

(C3) Therefore, there will still be war among the imperial powers, even under Russell's assumption of continental empires. (This contradicts RI.)

(C4) These wars will result in the hegemony of only one power. (This contradicts $\mathrm{R}_{4}$.)

(C5) Therefore, either Russell should desire the complete hegemony of the British Empire (a position which Russell was not willing to adopt), or failing that, Britain should respect the independence of other states, particularly that of the Boers (as Couturat had been advocating against Russell's positions).

What, then, of Russell's reply? Couturat had launched a major attack on his position, discovering a contradiction at the heart of his system-as indicated in $\mathrm{C}_{4}$ above. This contradiction put into doubt the foundations of Russell's theory of continental imperialism, just as
Russell had previously put Leibniz' system into doubt by showing that its axioms were contradictory - though, of course, the contradiction here is in a political, rather than a metaphysical, theory. Russell's next letter to Couturat was sent on 2I June, more than a month later, just before he left for the Paris conference on philosophy. But the spirit of defensiveness is gone, and, indeed, the debate seems resolved, though not to Russell's advantage. Russell indicated to Couturat: "I've saved all of your letters, from the beginning, that you have written to me. I can assure you that the political discussions, rather than offending me, have very much interested me, and that I hope to continue them in person at Paris" (2I June 1900). The meeting in Paris, at least according to Russell's account, did not deal with politics. ${ }^{2 I}$

There is no further reference to the question of the Boer War during I901, during which year Russell was hard at work on mathematical logic, but on 25 June 1902, just after the Peace of Vereeniging ended the war, Russell wrote to Couturat: "I am very delighted about the peace in Africa. The concentration camps greatly disgusted $m e,{ }^{22}$ and I find myself much less imperialistic than before. But for the most part the peace conditions seem good." ${ }^{23}$ To this Couturat replied, noting that he recognized that Russell had changed his mind:

I am quite pleased with what you have said about peace in Africa. It was a relief for humanity. Unfortunately the evil that has occurred will be difficult to repair,

${ }^{21}$ Russell and Alys met Couturat and his wife for dinner in July of 1900, an event which Russell remembers as "stifling" for lack of fresh air (Russell to Morrell, 25 March 1912; the air anecdote is retold in Auto., 1: 134).

${ }^{22}$ The mention of the concentration camps is interesting in this context. Russell's wife Alys was a Quaker, and the Quakers had campaigned against the concentration camps. Although I'm not aware of any evidence of Alys' personal participation in such a campaign, her religious affiliation would certainly have resulted in her, and presumably Russell's, being aware of the disease and death in these camps. I thank Dr. Eleanor Godway of the cCsu Philosophy Department for bringing this point to my attention.

${ }^{23}$ In his private diary for 1902, Russell noted that his pro-Boer sympathies were also expressed at a dinner discussion: "On the roth [of December] I dined at the Courtney's, which was agreeable; she and I talked pro-Boer, and I got on with her very well" (Papers, Iż: 16, included as part of Russell's entry dated i3 Dec.). Catherine Courtney, née Potter, was a sister of Beatrice Webb and an anti-imperialist and a leader of the English supporters of the Boers during the war (ibid., 453). 
the moral evils especially. My opinions haven't changed one iota concerning the facts; I am pleased to see that yours have changed. Imperialism is a folly which will be most costly to Great Britain, I'm afraid, and which has garnered for her the hostility of all of Europe (that of France is nothing in comparison to that of Germany). This is too bad for the friends of England and of peace. In my country the nationalists ["jingos"] have been beaten; this does much for the tranquillity of France and of Europe. (8 July 1902; emphasis added)

By 1903, Russell was engaged in political action over free trade, opposing the imperialist policy of protection. "Political affairs in my country are disturbing. I am passionate for free trade; moreover, I've completely abandoned imperialism" (20 June 1903), a point which he repeats in the 5 October 1903 letter referred to but not quoted from by Ryan above: "Yes, like many other Englishmen, I have completely given up on imperialism, which had stirred up the image of the country in danger. ${ }^{24}$ This concluded the debate. ${ }^{25}$

In opposition to Russell's own claim in his Autobiography, his shift from a liberal-imperialist defence of the British in southern Africa to the beginning of anti-imperialist stance was not initiated by his "conversion" experience of 190I. Rather, the conversion experience, in so far as it dealt with war and peace, was prepared by the debate between Russell and Couturat in the preceding year.

24 Russell's formulation in French of his position is "Oui, je suis revenu completement comme beaucoup d'autres Anglais, de l'impérialisme, qui avait suscité le spectacle de la patrie en danger." I have translated "revenu" in the first phrase of the sentence as "given up on", though the term in its more prosaic use means "come back from", as in travelling to a destination and then returning. In a metaphorical sense, Russell had been on a "voyage" in sympathy with British imperialism, but his trajectory had been stopped and reversed as a result of Couturat's critiques.

${ }_{25}$ Russell and Couturat continued to exchange letters, though intermittently after 1907. Their final exchange was in 1912-13. Russell wrote to invite Couturat to a congress of mathematics to be held in August 1912 (16 March 1912), in which he expressed the hope that Couturat would put aside his work on Ido to return to "your first love ... the principles of mathematics". Couturat, however, declined, stating: "I can only preach for my saint, that is to say, the international language" (20 March 1912). The last letter to Russell from Couturat (30 Dec. 1912) complained of Peano's opposition to Ido and his proposal of an "Italianized" alternative international language, provoking Russell's ire about the futility of the whole project in his note to Ottoline Morrell cited above. Russell's last letter to Couturat in the Russell Archives is dated 7 January 1913 and communicates Russell's rejection of a manuscript by a third party which Couturat had sent to Russell.
Against Ryan's claim that Russell defended a moderate imperialist viewpoint as late as 1903 , we see that already in 1902 -immediately after the peace treaty ending the Boer War-Russell was sufficiently propeace that Couturat recognized that Russell had changed his position. ${ }^{26}$ By 1903 , Russell was engaged in political action against the imperialist policy of protectionism. But the basic change in Russell's thinking had occurred some three years earlier, as a result of Couturat's reductio argument to which Russell did not and could not reply.

\section{RUSSELL'S CHANGE OF POSITION}

It is not unusual that Russell changed his position on an important question as the result of a spirited debate with a colleague. As an openminded thinker, Russell was strongly influenced by the views of those of his peers with whom he discussed basic issues, and their criticism of his views often led him to change his position. Examples include G. E. Moore's role in Russell's rejection of idealism in the I89os and Ludwig Wittgenstein's influence on Russell's views concerning logical atomism in the I9IOs. Louis Couturat's influence on Russell's views in the early I9oos on the lesser known topic of the Boer War was just as important as these were.

From what precedes it is clear that the 190I "conversion experience" did not initiate Russell's abandonment of imperialism and the British side in the Boer War. But did he really take until 1903 to switch his views, as Rempel and Ryan have claimed? The problem is complicated by Russell's silence between his letter of 21 June 1900 , when he indicated to Couturat that he had not been offended by his critique, and his letter

${ }^{26}$ As a result of this change of position, Russell's association with the Coefficients dining-club-a discussion group created by Sidney Webb in 1902 to debate issues related to the British Empire- was brief and unsatisfactory. He joined in September 1902 and resigned in July 1903. A note in Russell's journal for to December 1902 indicates that he agreed only with the New Zealand social reformer W. P. Reeves and the science-fiction author H. G. Wells. In Portraits from Memory (1956), Russell reflects on the experience: "I very soon found that I was too much out of sympathy with most of the Coefficients to be able to profit by the discussions or contribute usefully to them. All the members except Wells and myself were Imperialists and looked forward without too much apprehension to a war with Germany" (PfM, p. 82) See also Papers, 12: 15, 17-I8, and Auto., I: 153 . 
of 25 June 1902, when he wrote Couturat to approve of the peace treaty ending the conflict.

It might be argued that Russell was preoccupied with mathematica logic following the I-s August I9oo International Congress of Philosophy in Paris, and so was disinclined to reply to Couturat and defend his presumably still pro-imperialist position. Indeed, the following decade was largely taken up, in collaboration with Alfred North Whitehead, by the production of Principia Mathematica. But during this decade Russell did find time to participate in at least two political campaigns-for Free Trade in 1904, and for election to Parliament on a women's suffrage ticket in 1907. Russell, though deeply engrossed in his logical work, wrote extensively on both these topics. ${ }^{27}$ His silence about imperialism during 1900-02 cannot be seen as merely the effect of his absorption in work on logic.

Nor can Russell's silence from 1900 to 1902 be seen as neutral towards the claim that he had been refuted in his pro-imperialist stance by Couturat as of 1900 . Russell, to say the least, was not shy about making his opinions known: the tens of millions of written words he has left on every subject of interest to him is evidence to this fact. Couturat, in his letter of I3 May 1900 had formulated a reductio ad absurdum of Russell's "continental imperialist" position. No stronger challenge can be made to a logician's theory than to derive a contradiction at its core; recall the effect of Russell's paradox on Frege, who was devastated by its discovery. True, the theory here in question is a political one; but Russell had explicitly formulated it in an axiomatic fashion, so that a reductio argument could not be taken lightly.

Although Russell did not give up the basic theory of mathematical logic after the discovery of his paradox, the situation was far different with respect to the political theory of continental imperialism. In the former case, Russell worked to develop a "patch"-in the form of the theory of types-which would save the underlying theory. But in the latter case - the theory of continental imperialism-there is no documentary evidence of any attempt to formulate an equivalent modification of the theory which would preserve its essentials. Indeed, all the

27 See Papers 12, sections on "Defence of Free Trade", pp. I8I-238, and "Liberalism and Women's Suffrage", pp. 239-318. evidence points to the fact that in the period under question, following Couturat's letter of 13 May 1900 , Russell never again defended contemporary imperialism in any written statement, either in private or in public. As Russell himself later noted in his Autobiography concerning his correspondence with Couturat: "I corresponded with him for many years, and during the early stages of the Boer War wrote him imperialistic letters which I now consider very regrettable" (Auto., I: I34). The reference to the "early stages" is significant and, based on the above argument, refers to the period before 13 May 1900 and to Couturat's reductio ad absurdum.

When Russell returned to write on war and imperialism, in the context of his opposition to the First World War, he distinguished four types of wars: (I) wars of colonization, (2) wars of principle, (3) wars of self-defence, and (4) wars of prestige, of which the fourth alone applied to the events of $1914-18 .^{28}$ In his discussion of the first type of war, "wars of colonization", Russell was still under the influence of nineteenth-century anthropology, and accepted the distinction between "higher" and "lower" races. He believed that "though totally devoid of technical justification", wars of colonization had been nonetheless "justified by results", by which he meant the "survival of the fittest" and the spread of civilization to the "greater part of the earth's surface". ${ }^{29}$ But, he hastened to add: "Such wars, however, belong to the past." This position is rather removed from Russell's campaign a half century later supporting the struggle for liberation of a neo-colonized people in Vietnam. ${ }^{30}$ Yet it is still consistent with his rejecting, as of late 1900 , the

28 "The Ethics of War", in Russell, Justice in War-Time (Chicago and London: Open Court, 1916), p. 28; Papers, 13: 67. For Russell's pacifism during the Great War, see Jo Vellacott, Bertrand Russell and the Pacifists in the First World War (Hassocks, Sussex: Harvester P., 1980).

${ }_{29}$ "The Ethics of War", pp. 28-9; Papers 13: 67. It could also be argued that Russell went out of his way to defend past colonial wars, in order to make more evident his opposition to the present imperialist war. Defence of the former then becomes, in part, a thetorical device to win over non-pacifists (with respect to the colonial past) to his pacifist position on the Great War

${ }^{30}$ Russell's fully developed position against imperialist war and in support of colonized (or neo-colonized) peoples such as the Vietnamese can be found in his addresses to the International War Crimes Tribunal, which he was instrumental in organizing in 1967. See his opening and closing addresses in Against the Crime of Silence: Proceedings of the Russell International War Crimes Tribunah ed. John Duffett (New York: O'Hare 
imperialist justification of wars between "civilized" peoples: in the case at hand, between the British and the Boers, who were also of European (Dutch) extraction. ${ }^{3 \mathrm{I}}$

Further evidence for a significant change of position by Russell during the period closely following the 1900 debate with Couturat can be found in Russell's correspondence of April 1902 with the classical scholar Gilbert Murray. Russell corresponded with Murray for over half a century in hundreds of letters; it was Russell's attendance at Murray's reading of his translation of part of Euripides' Hippolytus which had immediately preceded the 1901 "conversion experience". A notable difference with pre-Couturat debate positions concerns Russell's view on utilitarianism. In his correspondence with Couturat two years earlier, Russell had begun his defence of continental imperialism with the comment, "I'm utilitarian"; he then continued to defend "bigger" interests against "smaller" ones (24 March 1900). But by 1902 Russell was so aware of the weakness involved in a urilitarian defence of a moral or political position that he declared to Murray that the ethical differences between them lay in the fact that Murray defended utilitarianism, whereas he did not: ${ }^{32}$

Books, 1968), and Prevent the Crime of Silence: Reports from the Sessions of the International War Crimes Tribunah founded by Bertrand Russell, ed. Ken Coates, Peter Limqueco and Peter Weiss (London: Penguin P., 1971).

${ }^{31}$ However, Russell did not make an absolute disjunction between colonial wars and imperialist wars of prestige. In Vol. 2 of his Autobiography, he comments in a letter of to August I918 to Lady Constance Malleson ("Colette") on Gladstone's decision to send General Gordon to Khartoum in 1885 : "It started the movement of imperialism which led on to the Boer War and thence to the present horror" (p. 87). This sentence postulates a conrinuity from one of the last British colonial missions-the relief of Khartoum then besieged by Sudanese forces - to the Boer War, and then to the First World War, which Russell from the beginning denounced as a war of prestige with no redeeming value.

${ }^{32}$ Russell's utilitarianism even at its height was somewhat diluted by Platonism, as indicated when he stated to Couturat, in addition to his affirmation of utilitarianism, that "I am no Kantian in ethics, but rather I'm more platonistic (as in logic) than anything else that is modern" (5 May 1900). In his letter of 3 April 1902 to Murray, Russell thing else that is modern" (5 May 1900). In his letter of 3 April that what first turned him away from utilitarianism was his choice (going back remarked that what first turned him away from utilitarianism was his choice (going back
to the 1890s) to pursue theoretical philosophy rather than economics or politics, though these latter had a greater likelihood of contributing more to human happiness. The search for an ethical theory would be one that would continue for all of Russell's life, and the relation between his logic, metaphysics, and epistemology, on the one hand, and his ethics, politics, and activism on the other remains a source of debate and contention today. See K. Blackwell, The Spinozistic Ethics of Bertrand Russell (London: Allen and
Our differences seem to spring from the fact that you are utilitarian, whereas I judge pleasure and pain to be of small importance compared to knowledge, the appreciation and contemplation of beauty, and a certain intrinsic excellence of mind which, apart from its practical effects, appears to me to deserve the name of virtue. What I want to discover is, whether you too do not hold moral principles not deducible from utilitarianism, and therefore inconsistent with it. (3 April 1902; Auto., I: I57)

Russell continued, pointing out that although he was for many years under the sway of the utilitarian viewpoint, he no longer was, the result of a change brought about through "moral experience":

I may as well begin by confessing that for many years it seemed to me perfectly self-evident that pleasure is the only good and pain the only evil. Now, however, the opposite seems to me self-evident. ${ }^{33}$ This change has been brought about by what I may call moral experience. (Ibid., 1: 158)

The referent of the term "moral experience" is not explicitly stated in the letter, and so is subject to interpretation, given the multiplicity of significant events which Russell experienced during the first two years of the twentieth century: the Boer War, including Russell's moral revulsion at the concentration camps; the "conversion experience", prompted by the agony of Mrs. Whitehead's pain; and the collapse of Russell's marriage to Alys, to which he had attached so much importance despite the objections of his closest family. ${ }^{34}$ This latter, though important, appears inconsistent as the sole referent of "moral experience", given the general nature of the problem which Russell goes on to discuss in the letter to Murray.

Unwin, 1985), for the argument that Russell based his ethics on Spinoza, rather than Mill, Kant, or Plato.

${ }_{33}$ Russell's reversal of the usual utilitarian formulation, with pleasure as evil and pain as good, is either a comment designed to emphasize his rejection of the standard utilitrian view, rather than his literal espousal of a new form of reversed utilaritarianism, or the limited product of the assessment of his failed marriage, where pleasure and pain had in fact become reversed. It is, in any case, a transitional moment in his move away from
strict utilitarianism to his later views on the "compossibility" of desires in Human Society in Ethics and Politics (London: Allen and Unwin, 1954).

34 I thank the referee who pointed out the ambiguity of the term "moral experience" and its possible reference to the personal, though I do not think that it refers uniquely or even principally to Russell's experience of the failure of his marriage. 
In contradiction to the view that "general maxims are to be found in conscience"- - an erroneous view which he traces back to the Ten Commandments-Russell defined the "true method of Ethics" as "inference from empirically ascertained facts, to be obtained in the moral laboratory which life offers to those whose eyes are open to it" (ibid.). The "empirically ascertained facts" and "moral laboratory" upon which ethical principles are to be founded provide a clue to the meaning of "moral experience", and rule out a reference limited to personal matters alone. Moral experience, if it is to be open to empirical scrutiny and form something like a laboratory environment, must include experiences of both personal and public matters. Otherwise, the ethical principles derived from the evaluation of moral experience would be too narrow to found a philosophy of the sort Russell desired, one which should include not only the consideration of personal, everyday life-such as love and marriage-but also the contemplation of impersonal mathematics and the abstract ideals of truth and beauty which Russell, in the same letter, held to be essential.

In his 5 May 1900 letter to Couturat, which centered on a utilitarian defence of imperialism, Russell said that the "middle" axioms of ethics have to be based on common sense. Common sense, in I90o, included the defence of British imperialism; but moral experience, in particular the debate with Couturat-reinforced by the horrors of the Boer War, especially the concentration camps-had led Russell to precisely the opposite conclusion. The argument of this paper is that the "moral experience" which brought about Russell's change to a non-utilitarian view in ethics, along with his abandonment of imperialism, included in an essential way the debate with Couturat and Russell's inability to respond to Couturat's reductio argument against his utilitarian-based theory of "continental imperialism".

Russell's concern for peace would express itself in a great variety of ways in the subsequent seven decades of his long life, as he struggled against war during the First World War, the inter-war period, the Cold War, and the Vietnam War. In a sense, the Boer War was Russell's Vietnam-forcing him to critically examine his own country's conduct in an imperialist adventure. Looked at from this perspective, Russell's critique of liberal imperialism was a lengthy process; indeed, it might be said that it lasted all the rest of his life, and was only completed by his radical stance against the war in Vietnam in the mid-rg6os. Then, he fully and explicitly took the side of an embattled colonized people in their struggle for liberation and independence. By that time he was in his nineties, having been twice dismissed or prevented from assuming university positions for his ethical and political beliefs, and having been twice imprisoned for his opposition to war. 